\title{
25 Big, environmentally friendly events
}

\author{
Sparing resources, respecting nature, \\ setting limits - an attempt by the \\ German Protestant Festival (Deutscher \\ Evangelischer Kirchentag) at organising \\ a big event on a sustainable footing
}

\section{Oliver Foltin, Christof Hertel, and Jobst Kraus}

\section{Introduction and objective of the article}

The objective of this chapter is to give an overview over the way the Kirchentag is organised in a sustainable manner. Furthermore, the chapter mentions and discusses measures that are implemented since a long-time or are currently invented.

The German Protestant Festival (hereinafter referred to as 'Kirchentag' (DEKT) or 'Kirchentag' Festival') takes place every two years in a German city. The cities chosen for the Festival over the last few years were Bremen, Dresden, Hamburg, Stuttgart as well as Berlin in 2017, where it was celebrated in conjunction with the anniversary of the Reformation and Dortmund in 2019. The Kirchentag Festival lasts five days, from Wednesday until Sunday. The participants, numbering more than 100,000 and covering all age groups, are predominantly Protestants while some may follow no or other faiths; they come from everywhere, from all parts of Germany and the world; approximately 80 nations are represented, and the visitors are above all young people half of whom are under 30 years of age (Pickel, Jaeckel \& Yendell 2015; DEKT n.d.). A Kirchentag Festival opens with a church service on Wednesday and ends with a final church service on Sunday. Kirchentag Festivals offer dedicated groups and initiatives a stage on which to present their concerns and projects. To this end, around 2,500 cultural, spiritual and social-policy events take place over the duration of five days (DEKT n.d.).

There are a variety of formats from workshops, exhibitions, concerts, church services to Bible work. During lectures and podium discussions, the most varied topics, aspects and issues concerning religious and social life, such as the fair organisation of a globalised world, the preservation of Creation and human dignity - are discussed with representatives from the world of politics, science, media, business, church and public life. At the 'Market of Possibilities' (Markt der Möglichkeiten), national as well as local church and social initiatives present themselves and their work to visitors of the Festival as part of a large exhibition. The Kirchentag Festival saw the light of day in 1949 as a movement of Protestant laymen who were brought together by their belief in Jesus Christ and their commitment to the Church and the 
world (Ueberschär 2017). The objective of the Kirchentag Festival was formulated in 1955 in the preamble of the 'Procedural Rules of the Deutsche Evangelische Kirchentag' and remains valid to this day: 'The Kirchentag Festival wants to bring together people who look for the Christian faith. It wants to gather Protestant Christians and strengthen their faith. It wants people to take on responsibilities within the Church and enable them to bear witness, serve the world and contribute to the community of worldwide Christendom' (DEKT 2015: 1).

The organisation and execution of the Kirchentag Festival would be impossible without the commitment of teams of volunteers, who are involved in planning and structuring the content of the event. The logistics and the on-site organisation too very much depend on the dedication of around 4,000 to 5,000 volunteers with youth ministry or scouts background. Overall, the preparation of each Kirchentag Festival takes around one and a half years with the organisers having access to a well-established organisational structure (DEKT 2019). The so-called 'Central Office' in Fulda acts as the permanent institution whose primary task is the selection of the topics to be covered at the Kirchentag. The actual organisation and direct execution of the event is the responsibility of the Field Office (Geschäftsstelle), which, every two years, sets up its headquarters in the respective host city. The costs for organising and carrying out a Kirchentag Festival amount to around 20 million euros of which 30 per cent are raised through the sale of entrance tickets, donations and sponsoring and which is supplemented by money provided by the respective host cities, federal states and federal-state churches as well as project funds (DEKT 2018a).

\section{Methodology}

The authors are partly members of the so-called counselling task force 'environment', one author is employed by the Kirchentag (DEKT) and works for environmental projects in the 'Field Office'. Besides counselling the organisation in questions of environmental management and proposing new projects, all of us were practically involved in some projects voluntarily. Under these circumstances, we took a quite critical look at the current way of organising mobility, procurement, energy consumption, nutrition etc and how the DEKT cope with planetary challenges and the practice of ecological management. In a certain sense, we didn't carry out a scientific study, but we tried to reflect the practice of DEKT critically and also in solidarity. Our aim is to challenge the DEKT to more efforts towards sustainability.

\section{Discussion: an eco-friendly event through environmental management at the Kirchentag Festival}

\section{Framework for environmental management}

A big event such as the Kirchentag Festival has, due to a large number of people gathering there, always both a direct and indirect impact on the 
environment. In Germany and Europe, however, the systematic environmental management of big events is still far from being the norm. Nevertheless, the benefits of environmentally conscious event planning are quite obvious: Apart from reducing the impact on the environment, it leads to cost savings due to a reduced and documented use of resources and helps convey a better image of the event among the public. Hence, the organisers of the Kirchentag Festival did, some years ago, set themselves the goal of organising the Kirchentag in a way that is as green and climate-friendly as possible. The aim was to reduce and/or restrict in particular the negative effects of an event of this size. As part of a project funded by the German Ministry of Environment and the Federal Environment Agency (Umweltbundesamt), the first eco-controlling exercise was introduced in 2003 which, apart from systematically recording the environmental effects of the Kirchentag Festival, evaluates the established indicators. The eco-controlling exercise was the basis that led to a further step in 2004 when, as per the EMAS Regulation, ${ }^{1}$ a validation of the Central Office in Fulda was undertaken (Cierjacks, Teichert \& Diefenbacher 2008). With the Eco-Management and Audit Scheme (EMAS), an environmental management system developed by the European Union, the environmental performance of companies and organisations of any size and from any industry can be continually improved. This ensures that environmental aspects are systematically taken into consideration. The ecomanagement system based on EMAS sees itself as a comprehensive environmental assessment tool aimed at reducing the usage of substances, materials and resources and at continually improving environmental performance. As the last step involving the 2007 Kirchentag in Cologne, the Field Office and the event itself were included in the EMAS evaluation and were successfully certified. Since then, the Kirchentag Festival has been the first and only big event in Germany that succeeded in permanently enshrining such an eco-management system (Umweltgutachterausschuss beim Bundesministerium für Umwelt, Naturschutz und nukleare Sicherheit 2017).

\section{Principles of environmental management of the Kirchentag Festival}

The foundation and basis of the environmental work of the Kirchentag Festival is its environmental policy and the guidelines formulated therein, which were last reviewed and updated in 2018:

Our environmental programme is a firm part of all fields of organisation. All co-workers receive intensive training and have the opportunity to present their ideas on the topic. The Board assumes commercial responsibility for topics involving the environment.

We consider environmental protection to be an ongoing process. While preparing, carrying out, following up on and administrating the Kirchentag Festival, we are continually striving for sustainability, which, to us, not only 
means complying with the applicable laws and standards but developing our very own standard. By using the EMAS eco-management system set forth in the EU Regulation, we undertake to continually and voluntarily improve our environmental performance. In conjunction with our suppliers and service providers as well as with the authorities, associations and other interested parties, we work out environmentally relevant standards. By doing so we reinforce sustainability within the value creation chain and in the public sector.

By analysing the environmental aspects within the life cycle of the Kirchentag Festival we recognise opportunities and risks within the organisational context. Through our own environmental programme and established environmental controlling, we continually improve our impact.

On account of the size of our event, we attach great importance to reducing resource utilisation and environmental impact with regard to energy and water consumption, transport, material procurement and catering, construction technology, use of land and waste disposal. We furthermore encourage a closed-loop cycle of resources.

The development and fostering of future-proof ecological alternatives constitute another priority of our environmental work. We explicitly want to increase the use of regenerative energy. We furthermore want to develop a sustainable mobility culture and use resources more intelligently by way of digital solutions.

Our material procurement and catering are geared towards being as ecological, fair and regional as possible. By doing so, we want to help producers, suppliers and traders, both regionally and worldwide, adopt an eco-friendlier approach.

Waste is to be avoided if at all possible. Unavoidable waste is preferably recycled or disposed of in an environmentally-friendly manner.

Through our public relations and educational work, we want to convey environmental knowledge to our employees, co-workers, business partners and participants, increase their environmental awareness and make them change their everyday behaviour in a way that has a lesser impact on the environment' (DEKT 2019: 7).

\section{Implementation of measures}

Before every Kirchentag Festival, current environmental goals are looked at in detail and further developed where necessary. The general intention is to minimise or, as far as possible, avoid in its entirety the use of natural resources and the emission of climate-warming relevant gases. Specific environmental goals are defined based on a comprehensive evaluation of the relevance of different environmental aspects and the resulting risks and opportunities with regard to the established environmental impact. Below, we refer to the 2017 Kirchentag Festival in Berlin to present the environmental goals as well as the measures that were implemented and discuss possible further developments with regard to the 2019 Kirchentag in Dortmund (DEKT 2019). 


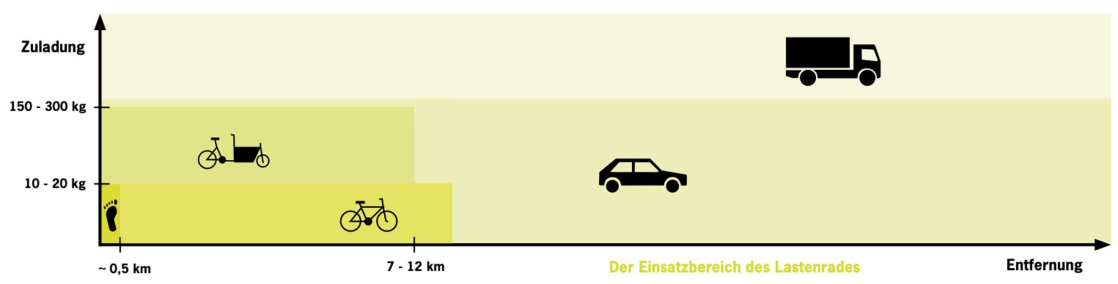

Figure 25.1 Filling the transport gap with cargo bikes since the Kirchentag Hamburg 2013. Source: Hertel \& Spott (2014: 12 f).

Catering - consuming organic and fairly traded products

Catering includes the consumption of food during the planning and execution phase of the Kirchentag Festival. During those stages at the 2017 Kirchentag in Berlin, around 170 tonnes of food were consumed. Based on the strategy that the 'Kirchentag isst ökofair' (the Kirchentag is about consuming organic and fairly traded products) and considering the enormous amount of food as well as its impact on production and processing, the 2013 Kirchentag in Hamburg developed and put into practice its own fair, ecological catering concept, which ensures that the catering is continually improved in terms of its environmental effects (DEKT 2019). The objective of the catering concept consists above all in reducing the use of valuable resources through a deliberate selection of food. Hence, the following guidelines apply to the procurement of food (DEKT 2019: 20):

- $\quad$ ecologically grown food;

- $\quad$ food from countries of the global South are fairly traded;

- considering regionality and seasonality of food;

- focussing on vegetarian and vegan options, offering small quantities of organic meat; and

- $\quad$ optimising quantity management.

As far as the catering for participants and helpers at the Kirchentag in Berlin is concerned, the proportion of food produced in line with the EU EcoRegulation was increased from around 50 per cent to more than 70 per cent. Specialist training sessions and workshops organised prior to the event led to greater awareness among the organisers of the 2019 Kirchentag in Dortmund 2019; the volunteers involved in choosing the (fully vegetarian) food options for gatherings such as the 'Meet and Greet' opening night of the Kirchentag, were given a cookery book titled 'Was für ein Geschmack' (What a taste), which had been specially developed for the event and was meant to assist them in implementing the standards set by the Kirchentag (DEKT 2019). In order to help the canteens develop a sustainable nutrition strategy for the Kirchentag, the transparent 'Gläserne Restaurant' practices seasonal, regional and organic 
dishes. ${ }^{2}$ To give hotels and conference venues an idea of how to meet the Kirchentag standards a brochure for chefs and managers was produced. ${ }^{3}$

\section{Mobility - the use of sustainable modes to and at the Festival}

One of the goals of the Kirchentag is to boost environmentally-friendly mobility options. Car and air travel are to be reduced through increased use of low-emission or no-emission means of transport such as trains and bicycles. Those who work for the Kirchentag itself are encouraged to do so by the organisers who provide them with a Bahncard 100 for frequent travellers, the option of video-conferencing and the use of cycle couriers during the event. Instead of using cars and vans to transport goods within the 'transport gap' (see Figure 25.1), 12 young volunteers with load bikes completed almost 500 jobs, covering $3.366 \mathrm{~km}$ with a corresponding reduction in $\mathrm{CO}_{2}$, nitrogen oxides and particulate matter (Hertel \& Spott 2014: 39).

At the 2017 Kirchentag in Berlin, for example, the number of the cycle couriers used to transport material between individual event locations was increased. By purchasing a plug-in hybrid car for the Field Office of the Kirchentag in Dortmund, the organisers were able to reduce fuel consumption during the planning stages of the Kirchentag (DEKT 2019). This does, however, only constitute a small part of the mobility concerning the Kirchentag. The mobility options provided to the volunteers and participants of every Kirchentag are much more relevant. What is primarily needed here is a change of awareness through information on environmentally compatible alternative ways of travel and offers available. According to transport statistics, 23 per cent of the visitors of the Kirchentag Festival travels to the event by car while more than 70 per cent use trains and buses/coaches (DEKT 2018b). Since 1981, entrance tickets for the Kirchentag have included a ticket for public transport in the respective host city (HVV 2015: 21). In most cases, people can get from A to B by walking or by hiring bikes, which the Kirchentag makes available in conjunction with the respective suppliers. Participants registering online for the Berlin Kirchentag could furthermore use a link to compensate for their emissions by making a voluntary payment to a respective supplier (DEKT 2019).

\section{Energy-split and remaining emissions}

During the 2017 Kirchentag in Berlin, around 85 per cent of the electricity used for preparing and carrying out the event was generated ecologically via regenerative sources of energy. To this end, a cooperation agreement was signed with a respective provider who, for the duration of the event, supplied the open-air stages and exhibition halls with the necessary power and who was independent of the coal and nuclear energy industry. The site in Berlin turned out to be quite vast compared with other host cities. Furthermore, there were fewer participants than expected, which meant that, compared with other Kirchentag Festivals, more fuel was used and too much material was procured, 


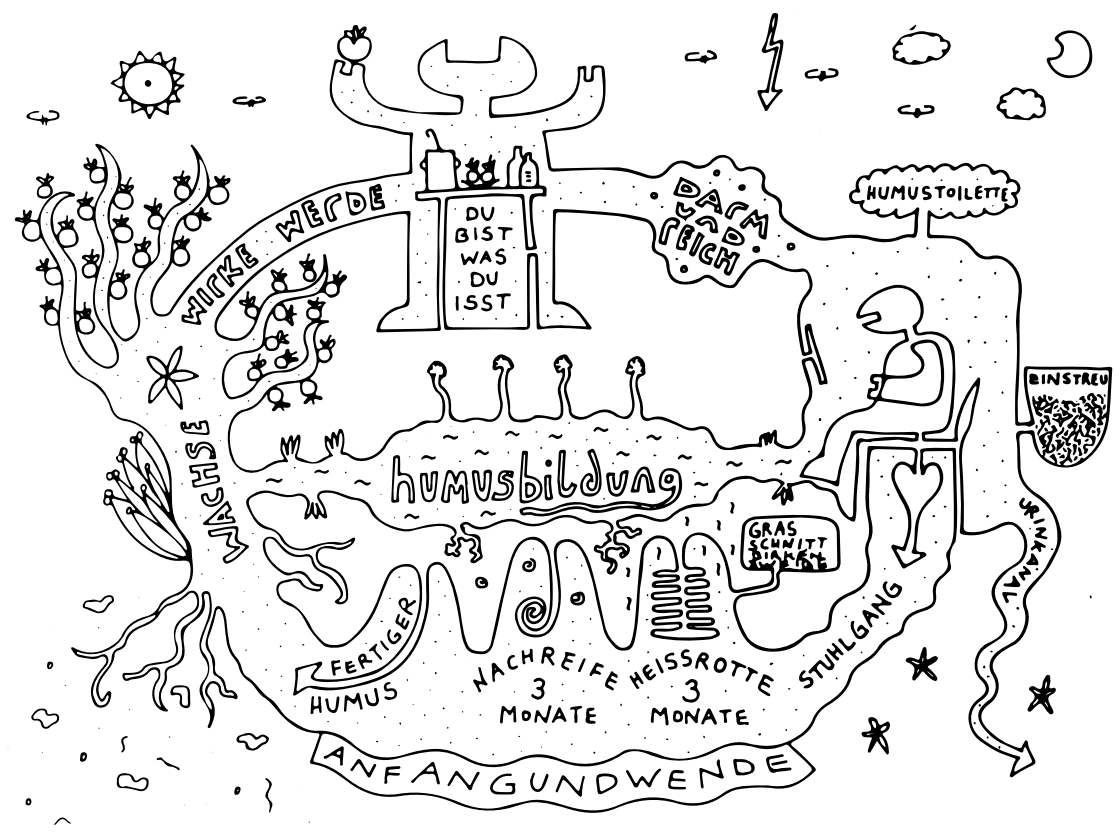

Figure 25.2 Humus Bildung - Humification-Education. Postcard designed for the Kirchentag compost-toilet project 2015.

Source: Bruno Nagel, www.sprachbehausung.de 2015.

which led to an increase in energy and emission values absolute and per head (DEKT 2019).

\section{Sustainable procurement of products and services}

The Kirchentag Festival in Berlin succeeded in further enhancing sustainable procurement. The textiles, for example, that were for sale at the Kirchentag shops were exclusively made from organic cotton. Besides, more than 90 per cent of all publications on offer at the Kirchentag was printed on recycled paper. The use of disposable carpets in the exhibition sections of the trade fair area has, for many years, been reduced. Where carpets cannot be dispensed with, carpet tiles are used, which, following the Kirchentag, can be re-used at other trade fairs. In addition, the offices of the Kirchentag are cleaned with predominantly ecological cleaning agents (DEKT 2018b).

\section{Waste reduction and recycling}

As soon as the events are being planned and the Kirchentag Festival enters the preparatory phase, a calculation of the necessary as well as the ordered and procured quantities for a multiplicity of products must be undertaken. At the 


\section{Oliver Foltin et al.}

Kirchentag in Berlin, a specially developed orientation tool for the co-workers was used listing the material and quantities for the many event formats on the basis and experience of previous Kirchentag Festivals. In addition, the procurers are trained to thoroughly review the required quantities as far as their purpose is concerned (DEKT 2018b).

Many of the items on offer at the Kirchentag shop cannot be sold during one Kirchentag Festival. To make products less perishable, general claims without year and city are used, to ensure that these items can be sold at a later date. Left-over textiles such as unsold Kirchentag scarves are, among other things, re-used in small upcycling projects. A workshop for disabled people, for example, turned 2000 scarves from Berlin into bedding that is sold online via kirchentag.de/shop. The Festival set up water stations that form part of socalled information towers where bottles and cups can be refilled. The use of deposit crockery and refillable drinks bottles is the rule at the 'Meet and Greet 'opening night of the Kirchentag Festival and whenever food and drink is provided to the helpers (DEKT 2019).

\section{Responsible water consumption}

Due to the water available at public water stations during the event and the frequent use of tap water during meetings, water consumption is somewhat higher than if bottled water were used. The organisers of the Kirchentag Festival are aware of this and accept it because, to them, the frequently superior tap water quality and a reduction of waste are an essential priority. In order to reduce water consumption, the organisers of past Kirchentag Festivals tried to use composting toilets. The advantage of composting toilets is that they do not require water and chemical additives and that, if the composting is performed by experts, the 'muck' left behind by the visitors of the Kirchentag Festival is turned into fertile humus soil (DEKT 2019; see also Figure 25.2 for an artistic view on the process). ${ }^{4}$

\section{Environmental communication and employee trainings}

Apart from the external communication of environmental topics and successful case studies, internal communication in the form of employee training sessions is an important factor to ensure the acceptance and implementation of environmental measures. An internal wiki called $\mathrm{KiWi}$ is a major base for knowledge transfer for environmental issues from one Kirchentag to the next one (DEKT 2019).

\section{Kirchentag adapting to climate change-related weather extremes}

By introducing the project 'Climate Change Adaptation of Big Events based on the 37th Kirchentag Festival in Dortmund in 2019' the Kirchentag Festival has added another dimension to its environmental work. The project, which is 
funded by the German Ministry of the Environment, consists of an attempt at adapting big events to the consequences of climate change. These climate change adaptations are summarised in a guideline and be made available to other event organisers in the future. The project involved the definition of around 35 measures ${ }^{5}$ that refer above all to the adaptation to climate signals such as heat, heavy rains, storms and thunderstorms. They were implemented, and their effectiveness reviewed at the 2019 Kirchentag Festival in Dortmund. Apart from safety issues and questions involving event technology, it is above all about enhancing the awareness of the participants and using available resources such as cool or shady places as preventative measures (DEKT 2019).

\section{Perpetuated environmental standards applied by the Kirchentag Festival}

In addition to these measures for the Kirchentag Festival, there is a range of established environmental standards of the Kirchentag that have become a matter of course for many years. The most important are listed below (DEKT 2018b, 2019):

- Office material of past Kirchentag Festivals is re-used.

- The Central Office and, if possible, the Field Office is powered by green electricity.

- The energy-saving default is pre-set on all computers, monitors and printers.

- The default setting when it comes to printing documents on all printers and computers is the 2-sided, black-and-white standard.

- The publications contain references to the quality of the recycled paper.

- Collection points for various special types of waste (CDs, batteries, energy-saving lamps, toner cartridges).

- In the offices and meetings, rooms, boards and table displays contain information about environmental management.

- During tendering, preference is given to regional service providers and companies with a good ecological track record.

- Obligatory Training courses for employees are organised that cover the environment and environmentally friendly behaviour.

- During the event, cycle and cargo-bike couriers are also used for logistics (see youtu.be/fH0-ilgRneQ for the emission-free logistics project in 2013 in Hamburg).

- Each unit within the Field Office is provided with at least one service bicycle.

- 'Paper waste' printed on one side only is used to produce scribbling note pads.

\section{The results of environmental controlling of the Kirchentag Festival}

Pursuant to the EMAS Regulation No. 1221/2009, the eco-management system of the Kirchentag must fulfil specific requirements when it comes to 


\section{Oliver Foltin et al.}

the establishment and presentation of key figures. To this end, so-called vital indicators are used to convey environmental achievements. This is meant to ensure a transparent presentation of the environmental successes and a comparison between the different Kirchentag Festivals to make potential changes visible. All EMAS reports could be downloaded on kirchentag.de/umwelt. The key environmental indicators collated by the Kirchentag cover energy sufficiency, water, waste, material use, bio-diversity and emissions. The period covered by environmental controlling at a Kirchentag always includes the entire preparatory and planning stage as well as the time when the actual event takes place. As far as the presentation of the figures that follow the absolute figures for this two-yearly period are halved. This is in line with EMAS Regulation referring to one calendar year and to the number of permanent visitors to a Kirchentag as a reference value. (DEKT 2018b). The figures collated in the field of energy efficiency suggest that the annual use of electricity per permanent participant and based on a reference value of about 105,000 permanent participants per Kirchentag, has been reduced from $6.0 \mathrm{kWh}$ at the 2013 Kirchentag in Hamburg to $3.8 \mathrm{kWh}$ at the 2017 Kirchentag in Berlin. The annual water consumption per participant, however, has risen from 67.1 litres to 74 litres over the same period. The amount of waste was, however, kept at the same level of around $0.5 \mathrm{~kg}$ per permanent participant. The same applies to material consumption which, since the 2013 Kirchentag only rose slightly from $0.65 \mathrm{~kg}$ to $0.79 \mathrm{~kg}$ at the 2017 Kirchentag. The entire annual emissions of greenhouse gases $\left(\mathrm{CO}_{2}\right.$ equivalent) have increased slightly and risen from $29.8 \mathrm{~kg}$ to $36 \mathrm{~kg}$ per permanent participant. Overall, the 105,000 permanent participants of the Berlin Kirchentag including its preparation caused carbon dioxide emissions of around 8,000 tonnes (DEKT 2018 b). One must, however, take into consideration that one cannot always compare the figures of one Kirchentag Festival with those of another. Many environmental effects depend on the circumstances on-site. Nevertheless, the environmental indicators help establish a framework of measurable environmental effects within which the execution and organisation of a Kirchentag Festival are to take place and which can be continually improved through the implementation of the measures.

\section{Outlook: conclusion and recommendations}

The DEKT has achieved some things that are worth seeing, but on which it is not possible to rest. Like all major events, it continues to be challenged both nationally and internationally in view of the global challenges. In order to further reduce its ecological footprint step by step, it is not enough to be a kind of real laboratory for sustainable development for the respective host city and to strengthen existing transformation approaches by taking up local-regional issues with commitment. Rather, it seems necessary to us that, in addition to the continuation of an ambitious sustainability course, the Kirchentag, as an advance requester on the market, also initiates sustainable innovations vis-à-vis 
trade fair companies and producers. Ultimately, DEKT must also ask itself what the transition to a post-fossil society means for the organisation of events and what is a tolerable size for such an event. Efficiency cannot and must not then be the sole yardstick. In addition, there is the challenge as a learning organisation to look for concretions of a culture of sufficiency that can be practically lived by visitors, participants and organisations. To pass on these experiences to new employees, but also nationally and internationally to other event organisers with reports on their experiences and in the discourse, also in order to benefit from them, will remain an important and challenging task.

In view of the challenges of not crossing the planetary borders, not exceeding the Paris climate target of 1.5 degrees Celsius, and also as an organiser of major events to take care of the implementation of the Sustainable Development Goals, all major events - party conventions, city or sports festivals, trade fairs, etc. should enter into a cheerful competition with the Kirchentag for the most environmentally friendly and sustainable event. This would have several positive effects. Here are three of them:

- Suppliers and service providers (e.g. caterers) must adapt to new requirements - and if several do so, the pressure to change increases.

- When green events become mainstream, politics is increasingly required to follow suit and create the necessary framework conditions (or abolish them).

- Event visitors are increasingly confronted with a new culture of food, mobility, infrastructure etc. and motivated to change their own behaviour.

\section{List of abbreviations}

CD compact disc

$\mathrm{CO}_{2}$ carbon dioxide

DEKT Deutscher Evangelischer Kirchentag (German Protestant Church Festival)

EC European Commission

EMAS Eco-Management and Audit Scheme

$\mathrm{kg} \quad$ kilogram

kWh kilowatt hour

sqm square metre

\section{Notes}

1 See ec.europa.eu/environment/emas/index_en.htm.

2 See youtu.be/UBN2dplKIYY.

3 See dxz7zkp528hul.cloudfront.net/production/htdocs/fileadmin/dateien/zzz_NEUER_ BAUM/Ueber_uns/Umweltengagement/PDF/KleVer/DEKT34_Leitfaden_Klever.pdf.

4 See also youtu.be/k3J1hq3w9zk.

5 See www.klimaangepasst.de. 


\section{References}

Cierjacks, A., Teichert, V., and Diefenbacher, H. (2008). Umweltmanagement von Grossveranstaltungen. Heidelberg: Forschungsstätte der Evangelischen Studiengemeinschaft e.V.

DEKT (ed.) (2015). Ordnung des Deutschen Evangelischen Kirchentages. Retrieved from https://dxz7zkp528hul.cloudfront.net/production/htdocs/fileadmin/dateien/ zzz_NEUER_BAUM/Ueber_uns/Organisation/DEKT_Ordnung_des_Deutschen_ Evangelischen_Kirchentages.pdf.

DEKT (ed.) (2018a). Finanzen So wirtschaftet der Kirchentag. Retrieved from www. kirchentag.de/ueber_uns/finanzen/.

DEKT (ed.) (2018b). Aktualisierte Umwelterklärung 2017 des 36. Deutschen Evangelischen Kirchentages nach der EMAS-Verordnung Nr. 1221/2009. Retrieved from https://dxz7zkp528hul.cloudfront.net/production/htdocs/fileadmin/dateien/ zzz_NEUER_BAUM/Ueber_uns/Umweltengagement/PDF/Umweltmanagement/ DEKT_aktualisierte_Umwelterklaerung_2017.pdf.

DEKT (ed.) (2019). Eine Bestandsaufnahme vor dem Deutschen Evangelischen Kirchentag in Dortmund 2019 mit den Standorten Zentrales Büro Fulda und Geschäftsstelle Dortmund sowie den Umweltbilanzzahlen der Jahre 2010 bis 2018 vom Zentralen Büro. Fulda: Verein zur Förderung des Deutschen Evangelischen Kirchentages e.V. Retrieved from https://dxz7zkp528hul. cloudfront.net/production/htdocs/fileadmin/dateien/zzz_NEUER_BAUM/Ueber_uns/ Umweltengagement/UEberarbeitete_Seiten/Umwelterklaerung_Dortmund.pdf.

DEKT (ed.) (n.d.). Was ist Kirchentag? Wie er ist. Was er will. Woher er kommt. Retrieved from www.kirchentag.de/ueber_uns/was_ist_kirchentag/.

Hertel, C. and Spott, M. (2014). Leitfaden Lastenräder einsetzen. Bei Großveranstaltungen, in Großeinrichtungen. Stuttgart: 34. Deutscher Evangelischer Kirchentag Hamburg 2013 e.V. Retrieved from: https://dxz7zkp528hul.cloudfront.net/production/htdocs/fileadmin/ dateien/zzz_NEUER_BAUM/Ueber_uns/Umweltengagement/PDF/Lastenrad/DEKT34_ Leitfaden_Lastenraeder_einsetzen.pdf.

HVV (ed.) (2015). 50 Jahre HVV. Magazin. Jubiläumsausgabe 2015. Hamburg. Tempus Corporate $\mathrm{GmbH}$.

Pickel, G., Jaeckel, Y., and Yendell, A. (2015). Der Deutsche Evangelische Kirchentag - Religiöses Bekenntnis, politische Veranstaltung oder einfach nur ein Event?. Baden-Baden: Nomos.

Regulation (EC) No 1221/2009 of the European Parliament and of the Council of 25 November 2009 on the voluntary participation by organisations in a Community ecomanagement and audit scheme (EMAS).

Ueberschär, E. (ed.) (2017). Deutscher Evangelischer Kirchentag. Wurzeln und Anfänge. Gütersloh: Gütersloher Verlagshaus.

Umweltgutachterausschuss beim Bundesministerium für Umwelt, Naturschutz und nukleare Sicherheit (ed.) (2017). 36. Deutscher Evangelischer Kirchentag erhält EMAS-Ehrenurkunde. Retrieved from www.emas.de/aktuelles/2017/30-05-17-kirchentag-emas-ehrenurkunde/. 